THE OXFORD UNIVERSITY MUSEUM.' $\mathrm{FEW}$ buildings devoted to the pursuit of science - have a more interesting history or a more distinct individuality than the Oxford University Museum. It is the resultant of many of the most structure itself, which is Gothic both in conception and in detail, in the blend of the conventional and the realistic in its scheme of decoration, and in the array of statues which, forming an integral part of the design, carry the mind of the observer from Hunter and Harvey back through the ages to Hippocrates and Aristotle. But the outlook of the University is to the future as well as to the past, and in the various annexes which have sprung up around the original building we see evidence of a desire to "let the dead bury their dead," and to enter frankly upon the task of meeting modern requirements with a single eye to practical efficiency. Still, whatever scientific developments may yet be in store, the Museum Court will, we may hope, always remain to testify to the fact that the future will be none the worse for having some of its roots in the past. It must be confessed that the organisation of scientific study in the university has hardly kept pace with the growth of scientific appliances.

characteristic activities, and embodies some of the There is still too much clinging to respectable but most extrnest aspirations of the latter half of the nine- antiquated methods in the system of college tuition, teenth century. The two chief lines of scientific and and, above all, in that of examinations. $A$ artistic effort which converged upon Benjamin Woodward's Gothic pile found their most typical exponents in Acland and Ruskin; each of them a genuine enthusiast, each with not a few of the faults of his qualities, and each destined to witness the realisation of some of his ideals and the failure of others in the fabric which forms an appropriate monument of their lifelong association.

The newer buildings which at the present day are grouping themselves around the central structure of the museum constitute with it an apt symbol of the manner in which the university has responded to the needs of scientific research and education in modern times. Oxford can never forget that she inherits a $\mathrm{grea}$ tradition--literary and artistic, as well as philosophical. When first aroused to a sense of her responsibility in view of modern scientific demands, her main endeavour was to graft the new upon the old. No

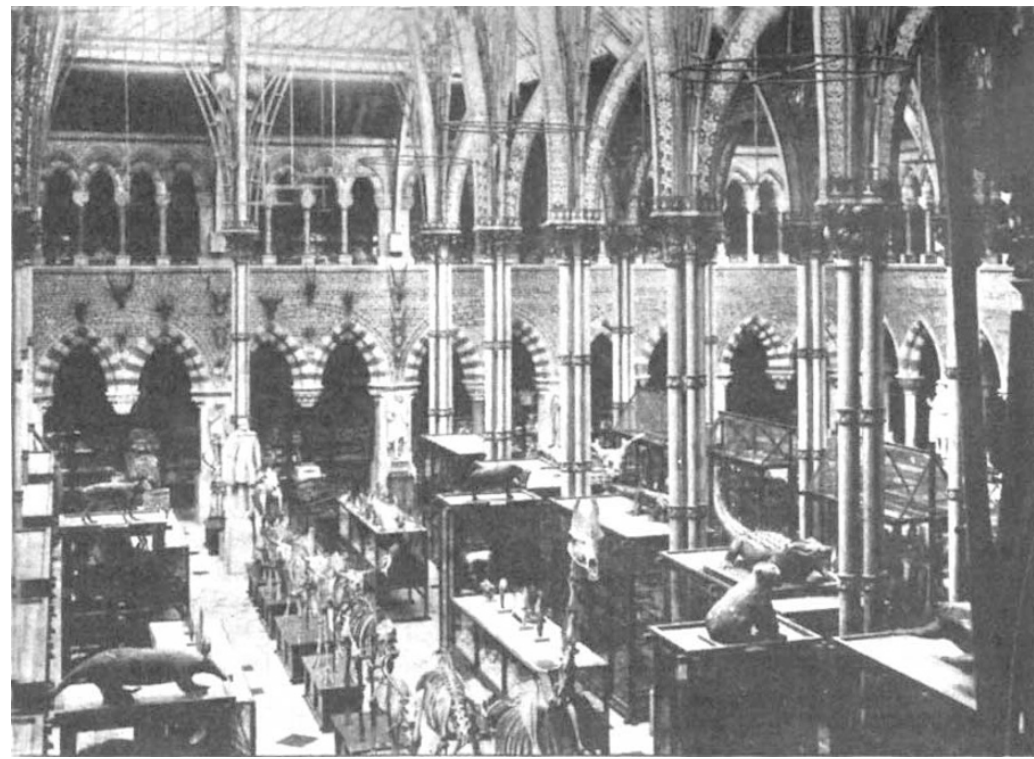
visitor to the original part of the museum can fail to recognise the outcome of this spirit in the

1 "A History of the Oxford Museum." By Dr. H. M. Vernon and K. Dorothea Vernon. Pp. 127. (Oxford: Clarendun Press, rgog.) Price rs. $6 d$, net.

No. 2102 , VOL. 82] 
*go8. Dr. and Mrs. Vernon have succeeded in presenting an admirable account of the progress of science in Oxford from the days when Willis, Bathurst, Seth Ward, and Robert Boyle held their meetings at the lodging of Wilkins, Warden of Wadham, in which college Sydenham and Wren were at that time undergraduates. The history of the struggries and ultimate success of the little band who, led by Acland, Daubeny, and Walker, with help from Pusey, resolved that, so far as in them lay, science should take its proper place among the activities of Oxford, is carefully and sympathetically recorded. The work of the museum during the fifty years of its existence-work associated with the names of Phillips, Brodie, Prestwich, Rolleston, Moseley, Lankester, and Burdon-Sanderson, to mention only a few-forms the subject of a specially interesting chapter; and the book ends with an account of the jubilee commemoration itself. We wish that the authors had found space to include in their record the address delivered on that occasion by Dr. Vernon Harcourt--an address justly characterised by them as "most instructive and entertaining." Extracts, however, are incorporated in the body of the work.

The book is attractively got up, and illustrated with some good photographic plates, in the legends of two of which, unfortunately, the points of the compass are incorrectly given. We reproduce views of the exterior and part of the interior of the original building.

F. A. D.

\section{THE DISTRIBUTION OF FRESH-WATER} EELS. ${ }^{1}$

$I^{T}$ is certain that the hydrographers of the Challenger and other deep-sea expeditions made their physical observations in the Atlantic Ocean depths all unsuspecting of the fact that thereby they were essentially helping to make an important contribution to the natural history of the fresh-water eel. Yet this fact constitutes part of the interesting information derived from a perusal of Dr. Schmidt's latest publication, a continuation of his previous famous researches upon the eel which have previously been described in the pages of NaTure.

In spite of the abundance and wide distribution of the genus Anguilla, the first and final chapters of its life-history were, until quite recently, matters of profound obscurity. It is a fact of common observation and knowledge that the elvers or glass-eels which in th: spring months ascend our rivers frequently in countless numbers develop into young eels, and also that adult eels in their silvery breeding dress descend to salt water in autumn; but there, until a few years ago, knowledge ended and conjecture began. It was a common belief in this country that estuaries and harbours probably afforded the spawning places. In I893 the Italian zoologists Grassi and Calandruccio proved that Leptocephalus brevirostris, a deep-water fish of obscure: systematic position taken in the Mediterranean, was really a larval stage of the common eel. Dr. Schmidt and his Danish colleagues, whose energies were first directed upon this particular research because of the economic importance of the eel-fishery in their country, traced the early "elver" stage down to the open sea, and at last, by their deepwater investigations in $1904-5$, succeeded in locating an important breeding region off the west coasts of the British Isles at depths of more than Iooo metres. Subsequent trawlings have revealed the distribution of the early (Leptocephalus) larval stage in the Atlantic Ocean from the Færoë Islands to Gibraltar, but always

1 On the Distribution of the Fresh-water Eels (Anguilla) throughout the World. (x) Atlantic Ocean and Adjacent Regions. A Biogeographical Investigation. By Johs Schmidt. With one chart. Pp. 45. (Copenhagen, Igog.)

NO. 2 I 2 , VOL. 82 in water of more than rooo metres depth and not less than $7^{\circ}$ temperature. From these investigations, Dr. Schmidt came to the conclusion that "in order to propagate, this species demands certain external conditions (chiefly great depths with high temperature and salinity of water)," and it was to test the validity of this conclusion for other parts of the world that the research upon the geographical distribution of the fresh-water eel was commenced.

The Anguilla genus is widely distributed, being found in the Atlantic as well as in the Indian and Pacific regions. However, the main point of this inquiry will be best indicated by limiting our consideration to the regions of America, Europe and Africa where most data are available, and where (if we except eastern Africa) the question is simplified by being confined to two species only, viz. Anguilla vulgaris, the European species, and $\dot{A}$. chrysypa, the American form. Now fresh-water eels are entirely lacking on the Pacific shores of North and South America (and of course in the river systems which have their outlet on this coast). On the Atlantic side, however, they are abundantly represented in the easternmost parts of Canada and the United States, and are found from southernmost Greenland and Labrador to the West Indian Archipelago and Guiana. On the other hand, they are lacking in South America south of Guiana, no single record, for example, occurring of the presence of fresh-water eels in the large river systems of Brazil and Argentina. They are found on practically all the islands of the Atlantic north of the Equator (Bermudas, Azores, Madeira, Canaries, Iceland, \&c.) and, what is especially worthy of attention, they occur on islands where other fresh-water fishes are completely lacking. On the eastern side of the Atlantic they are found from the region of North Cape and southwards along all the coast of Europe, on all coasts of the Mediterranean, and on the northwestern part of the coast of Africa. In Senegal they disappear, and are absent from all the rest of the west coast of Africa as far as Cape Colony, where the Indian Ocean species begin to be met with.

Thus in tropical, temperate, and even Arctic regions, Atlantic fresh-water eels are found-truly a widespread habitat, and one affording extremely varied environments! But it is on account of "this astonishing power to submit to most varied outer conditions" that their absence from certain regions is apparently incomprehensible. Why, for example, have they not been able to penetrate further southwards along the coasts of the Atlantic? In order to understand this, it is necessary to recall some of the results of later vears' marine biological investigations, especially "the ascertained fact that very often the sensitiveness of a species of fish to its surroundings differs a great deal in its growth-period and in its spawning-time, so that during the latter its requirements as regards the outer conditions (depth, temperature, salinity) are much more definite and very different from those during the first, the effect of which is that the distribution during spawning-time may often be very different from that during growth. . . It is in the first instance the requirements as regards the outer conditions during spawning time which influence the distribution."

The earlier investigations upon the spawning places of the eel have shown that in order to be able to propagate, the European fresh-water eel requires great depth (at least rooo metres), a high salinity (more than $35^{\circ} 2$ per cent.) and temperature (more than $7^{\circ}$ C.) at this depth; and this is where the importance of the hydrographical data obtained from the temperature curves of the Challenger, Valdivia, and other deep-sea expeditions comes in. It is shown that "the absence of eels in 